\title{
Pelatihan Branding Sebagai upaya Meningkatkan Efektivitas Pemasaran Nugget Lele Desa Mojogedang
}

\author{
Catur Sugiarto* \\ Fakultas Ekonomi dan Bisnis, Universitas Sebelas Maret
}

\begin{abstract}
Abstrak
Produk lele di Desa Mojogedang, Karanganyar sangat melimpah, namun warga masyarakat belum dapat memanfaatkan potensi sumber daya alam tersebut sebagai alternatif peningkatan nilai ekonomi daerah. Pelatihan pemasaran berupa branding produk diberikan pada warga dalam upaya membantu memasarkan produk nugget lele yang sebelumnya dikenalkan sebagai inovasi produk lele dan sayurmayur yang tersedia melimpah di daerah Mojogedang. Aktivitas pemasaran dan branding produk merupakan kunci keberhasilan produk untuk lebih dikenal oleh konsumen dan meningkatkan potensi penjualan produk. Pelatihan pemasaran sebagai bentuk pengabdian pada masyarakat ini diikuti oleh peserta dari anggota PKK Desa Mojogedang, Karanganyar.
\end{abstract}

Kata Kunci: Pelatihan, Pemasaran, Pengabdian, Nugget Lele

\section{Pendahuluan}

Penopang perekonomian masyarakat Desa Mojogedang didominasi hasil produk di sektor agraria, seperti pertanian, perkebunan, peternakan, dan perikanan. Berdasarkan sektor penopang perekonomian yang ada, masyarakat Desa Mojogedang, Karanganyar mayoritas berata pencaharian sebagai petani dan peternak. Salah satu sektor peternakan yang sering dibudidayakan oleh masyarakat Desa Mojogedang adalah budi daya lele. Selain mudah dalam perawatan, sumber air yang cukup melimpah menjadi faktor pendukung banyaknya masyarakat yang membudidayakan lele. Produk olahan yang dapat dihasilkan oleh lele juga sangat beragam antara lain adalah produk nugget lele.

Nugget lele merupakan salah satu produk olahan lele yang dikembangkan demi memecah kejemuan konsumsi lele secara langsung. Menu lele goreng maupun lele bakar yang sering dijumpai cukup membosankan. Selain itu, lele yang dijual secara langsung memiliki harga jual yang tergolong masih rendah, sehingga perlu adanya inovasi olahan lele yang dapat meningkatkan nilai produk berbahan lele sehingga harga jual produk olahan lele menjadi lebih meningkat.

Inovasi yang dikembangkan berupa nugget lele tidak hanya berbahan dasar lele saja, namun terdapat campuran sayuran untuk meningkatkan nutrisi pada produk jadi nugget. Dengan mencampurkan sayuran ke dalam olahan nugget, diharapkan nugget yang dihasilkan memiliki banyak manfaat kesehatan bagi masyarakat. Sayur digunakan sebagai alternatif campuran karena pada daerah lokasi pengabdian tersedia sumber sayuran yang melimpah sebagai sumber daya alam sektor pertanian dan perkebunan.

Produk nugget lele yang dihasilkan sebagai aktivitas awal warga tidak akan menambah nilai ekonomi jika tidak terdapat proses pemasaran yang memadai. Potensi besar dari nugget berbahan lele harus dikomunikasikan pada konsumen maupun calon konsumen. Strategi dan metode pemasaran yang efektif

\footnotetext{
* Penulis Korespondensi. Email: catursugiarto@staff.uns.ac.id
} 
perlu dirumuskan agar produk baru ini dapat diterima pasar di tengah persaingan produk jananan dan olahan lauk-pauk yang makin dinamis dan ketat.

Pemasaran menjadi kunci kesuksesan pada suatu proses bisnis, utamanya jika produk tersebut merupakan produk baru dan akan segera dikenalkan pada calon konsumen. Pada konteks ini, kegiatan branding adalah aktivitas yang perlu dipertimbangkan dalam upaya membentuk kesadaran (brand awareness) calon konsumen potensial pada merek nugget lele yang dihasilkan warga Mojogedang. Hal ini telah ditegaskan pada beberapa literature pada bidang pemasaran bahwa kesadaran terhadap merek dapat membantu konsumen dalam mengambil keputusan pembelian (Macdonald \& Sharp, 2000), memacu perilaku pembelian ulang (Hoyer \& Brown, 1990), dan pada gilirannya akan meningkatkan ekuitas merek (Huang \& Sarigöllü, 2014).

Berdasarkan fakta perlunya inovasi pemasaran pada produk nugget lele yang dihasilkan, maka program pengabdian pada masyarakat daerah Mojogedang, Karanganyar perlu dilakukan, utamanya pengabdian dalam bentuk sosialisasi dan pelatihan branding. Pelatihan ini diharapkan dapat meningkatkan nilai produk berbahan dasar lele yang dihasilkan, serta secara lebih luas dapat menumbuhkan potensi ekonomi daerah dan kesejahteraan masyarakat.

\section{Metode Pelaksanaan}

Desa Mojogedang adalah salah satu desa yang terletak di Kecamatan Mojogedang, Kabupaten Karanganyar, Provinsi Jawa Tengah. Desa ini terdiri atas 7 dusun, yaitu Dusun Mojogedang, Dusun Moho, Dusun Dersono, Dusun Klumpuk, Dusun Blimbing Mulyo, Dusun Gaden, dan Dusun Ploso dengan total 9 Rukun Warga dan 33 Rukun Tetangga. Desa ini memiliki potensi sumber daya alam yang cukup melimpah, namun warga belum mampu melakukan upaya optimal untuk memanfaatkan potensi tersebut.

Solusi yang ditawarkan pada mitra warga Desa Mojogedang adalah pembuatan nugget pada produk lele yang melimpah, serta lebih lanjut membantu memberikan pelatihan pemasaran produk tersebut dalam bentuk kegiatan branding dan pemasaran produk secara online. Pada pelaksanaan pengabdian ini, beberapa tahapan disampaikan:

1. Tahap pengenalan materi melalui contoh produk-produk yang sudah ada di pasaran. Pada tahap ini peserta dijelaskan bagaimana pentingnya merek dan penggunaan merek untuk mengenalkan produk, ciri pembeda dari produk lain dan sebagai fitur penting yang menjadi asset yang mahal bagi entitas bisnis.

2. Tahap penyampaian konsep dasar pemsaran secara umum dan implementasi konsep tersebut di pasar. Tahap ini menjelaskan konsep-konsep dasar pemasaran serta contoh perusahaanperusahaan yang telah berhasil dalam menggunakan pemasaran professional. Pada tahap ini juga disampaikan trend pemasaran, serta tips bagaimana membangun merek yang baik

3. Tahap sosialisasi cara pemasaran produk nugget lele yang efektif dan efisien melalui branding yang tepat. Pada tahap ini, dijelaskan Teknik pemasaran dan branding produk nugget lele secara spesifik dan upaya peningkatan nilai produk.

Peserta kegiatan pelatihan ini adalah anggota PKK Desa Mojogedang sebanyak 39 orang dan mahasiswa KKN Tematik Integratif yang berlokasi di Desa Mojogedang sebanyak 10 orang. Setelah sebelumnya masyarakat dikenalkan teknik pembuatan nugget lele, selanjutnya pada pelatihan ini peserta dijelaskan Teknik pemasaran produk tersebut. 
Jurnal SEMAR Vol. 8 No.2, 2019 hal. 1 - 5

ISSN: 2302-3937 | Copyright (C LPPM Universitas Sebelas Maret Homepage: https://jurnal.uns.ac.id/jurnal-semar

\section{Hasil dan Pembahasan}

Kegiatan Sosialisasi Marketing Nugget Lele untuk Meningkatkan Efektifitas dan Efisiensi Pemasaran Produk mendapatkan sambutan yang antusias dari anggota PKK Desa Mojogedang. Hal ini dibuktikan dengan semangat dari peserta dalam bentuk kegiatan tanya jawab yang diajukan kepada narasumber atau pembicara. Peserta kegiatan, khususnya anggota PKK Desa Mojogedang banyak menanyakan tentang cara dan kiat-kiat dalam memasarkan produk nugget lele. Para anggota mayoriyas mengalami kesulitan dalam hal memasarkan produk karena ketidaktahuan metode pemasaran yang tepat dalam mendongkrak penjualan produk. Melalui metode pemasaran yang menitkberatkan pada cara branding produk, para anggota PKK dirasa cukup mendapatka bekal dalam memasarkan produk yang ada.

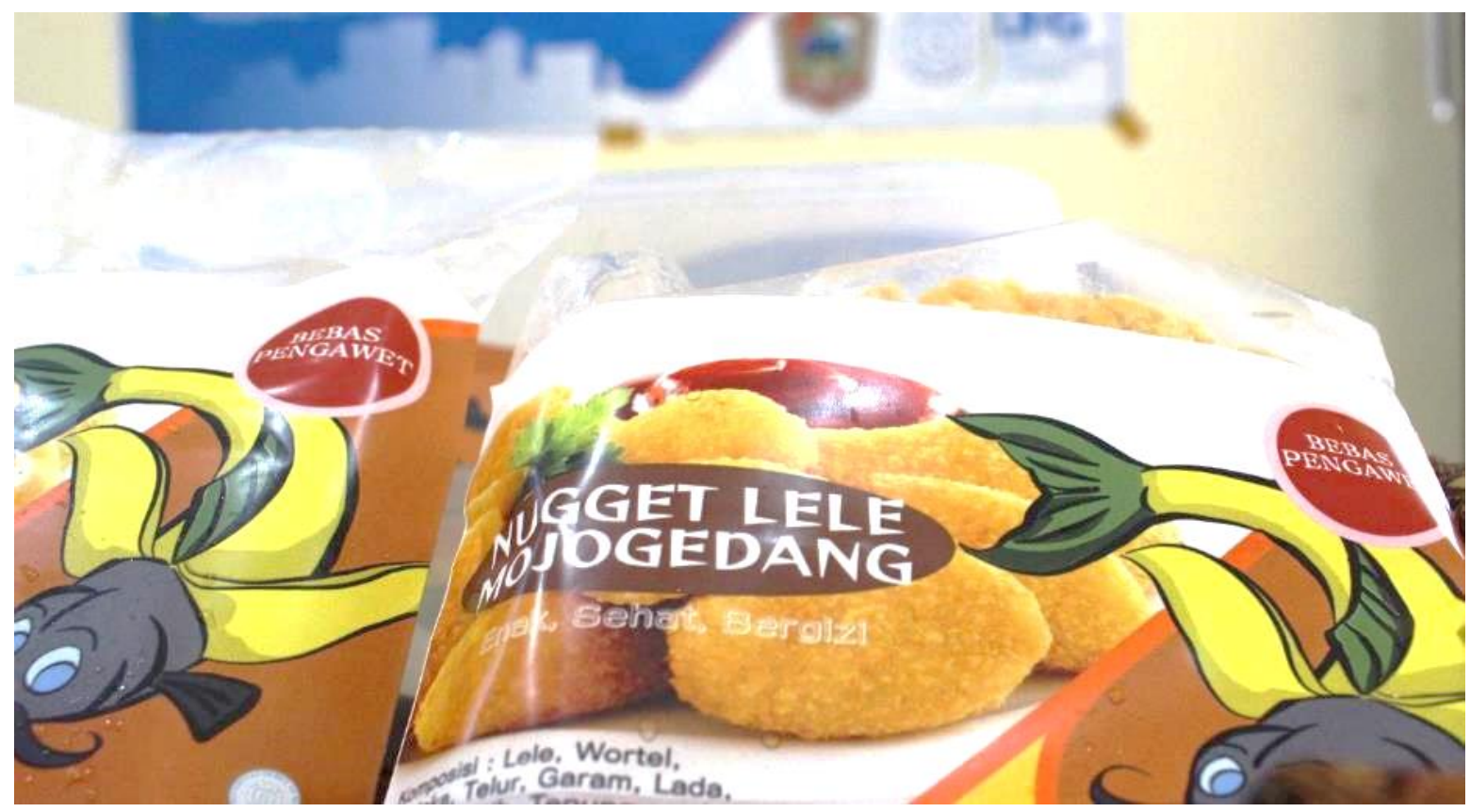

Gambar 1. Produk Nugget Lele Mojogedang

Strategi branding yang coba dikembangkan dalam memasarkan produk nugget lele dirasa cukup efektif dan efisien karena didukung dengan adanya media sosial yang berkembang pesat di kalangan masyarakat Indonesia secara luas. Branding produk dapat dilakukan melalui beberapa cara antara lain, membuat logo yang unik dan iconic serta jargon pendukung sehingga mudah diingat oleh masyarakat secara mudah dan cepat.
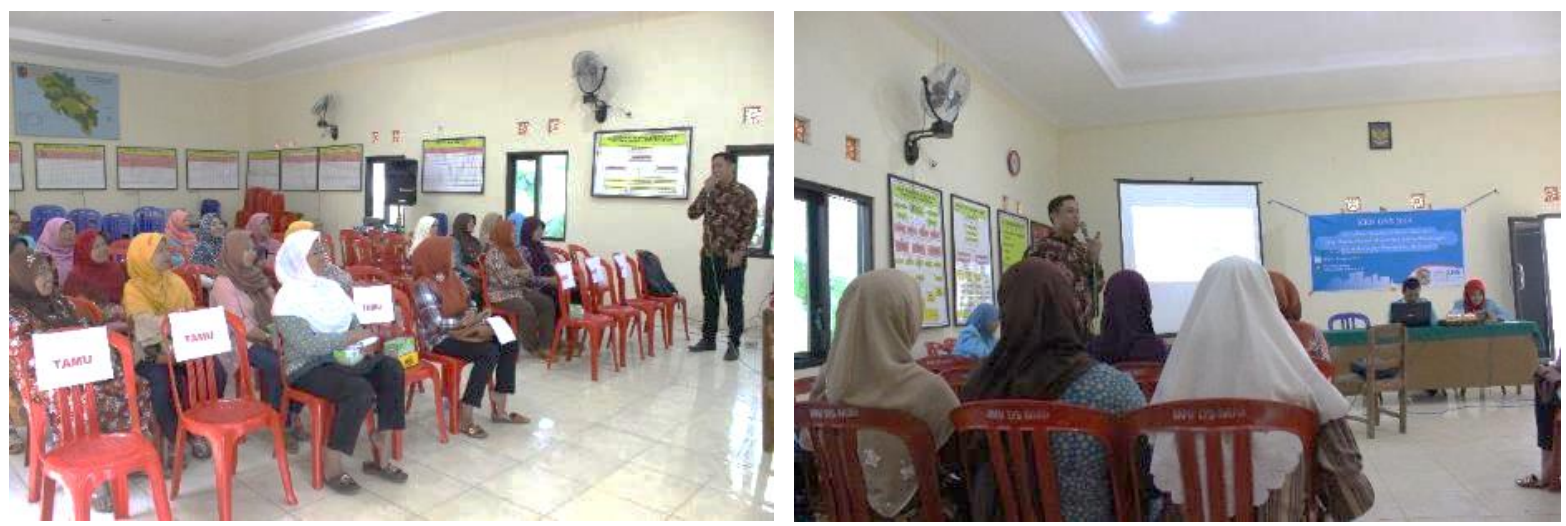

Gambar 2. Proses Pelatihan Pemasaran 
Alasan utama strategi branding dipakai dalam pemasaran suatu produk adalah sebuah brand ataupun merek yang sudah ternama dapat membuat nilai jual sebuah produk meningkat. Bahkan sebuah brand atau merk dapat mempengaruhi persepsi dan penilaian orang terhadap produk tertentu. Hal ini tentu saja dapat berpengaruh besar terhadap efektifitas dan efisiensi pemasaran produk.

Adapun rambu-rambu yang perlu diperhatikan dalam membangun brand dan merek yang baik, antara lain merek harus menggambarkan manfaat produk, berasosiasi yang baik, mempunyai kekhasan, dan mudah diingat serta diucapkan masyarakat umum. Beberapa kriteria tersebut harus terpenuhi dalam rangka membangun merek yang baik.

Media yang dapat digunakan sebagai sarana pemasaran produk antara lain media sosial karena tidak membutuhkan biaya yang banyak. Sebenarnya banyak media yang dapat digunakan sebagai media pemasaran, tidak hanya media sosial. Namun media seperti iklan berbayar dirasa cukup membebankan produk lokal yang masih kurang dalam segi modal sehingga media sosial dipandang lebih dapat membantu pemasaran secara efektif khususnya dari segi pembiayaan.

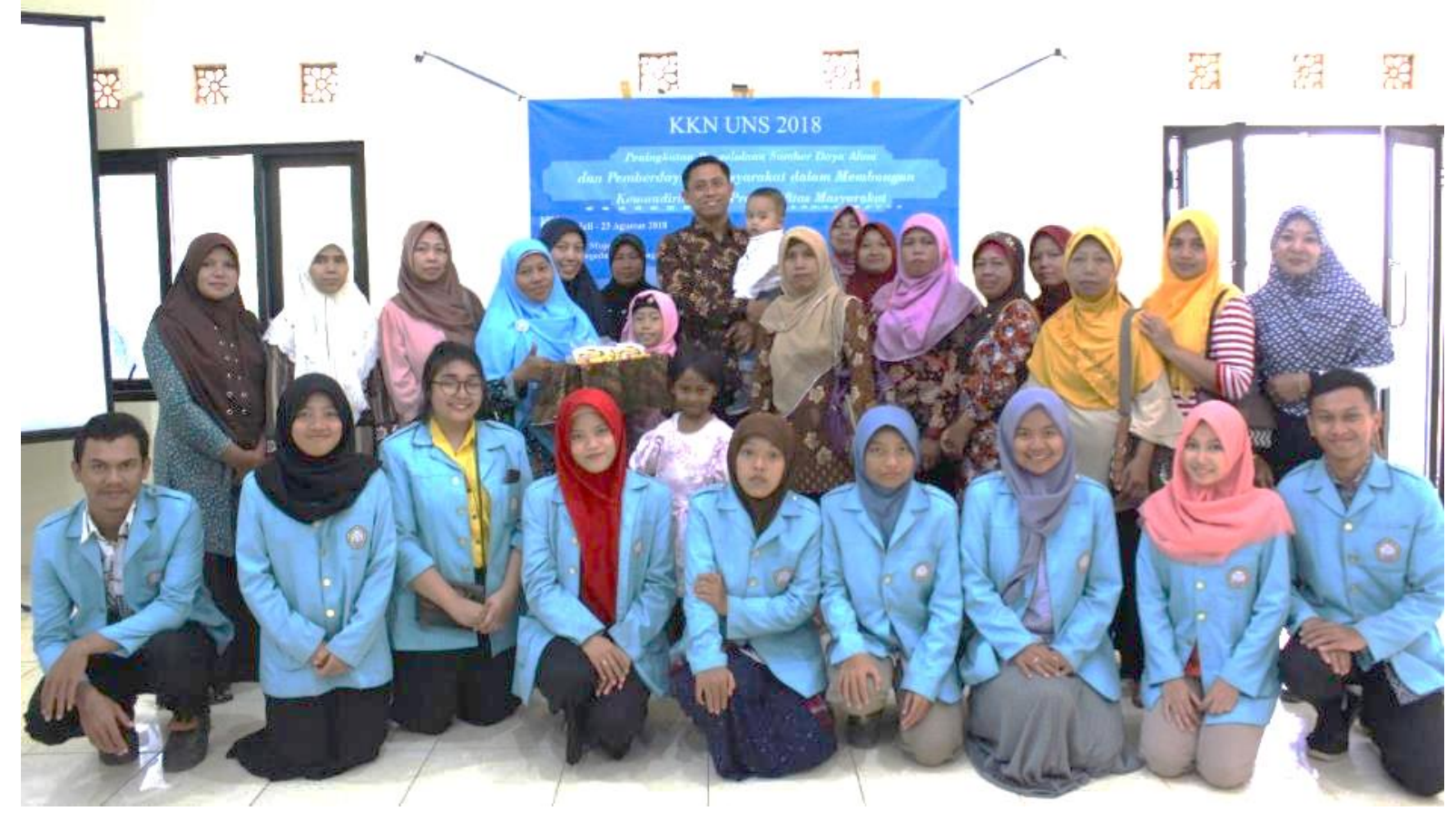

Gambar 3. Peserta Pelatihan

\section{Penutup}

Proses pengabdian pada masyarakat pelatihan dan sosialisasi pemasaran nugget lele terlaksana dengan baik. Peserta warga Mojogedang, Karanganyar antusias dalam mengikuti setiap sesi dan materi pelatihan. Proses pelatihan sangat dinamis dan peserta aktif memberikan pertanyaan serta diskusi berjalan dengan baik. Warga menyampaikan bahwa pelatihan semacam ini sangat bermanfaat dalam pengembangan diri warga utamanya dalam aspek kewirausahaan. Pada sesi akhir pelatihan, warga, didampingi oleh mahasiswa dari UNS langsung mengimplementasikan konsep pemasaran dan materi pelatihan langsung dengan membuat akun marketplace dan media pemasaran online. Melalui pelatihan dan program pengabdian semacam ini diharapkan mampu mengembangkan potensi masyarakat dalam memanfaatkan sumber daya daerah yang melimpah. 
Jurnal SEMAR Vol. 8 No.2, 2019 hal. 1 - 5

ISSN: 2302-3937 | Copyright @ LPPM Universitas Sebelas Maret

Homepage: https://jurnal.uns.ac.id/jurnal-semar

\section{Referensi}

Hoyer, W. D., \& Brown, S. P. (1990). Effects of Brand Awareness on Choice for a Common, RepeatPurchase Product. Journal of Consumer Research, 17, 141-148.

Huang, R., \& Sarigöllü, E. (2014). How Brand Awareness Relates to Market Outcome, Brand Equity, and the Marketing Mix. In T.-M. Choi (Ed.), Fashion Branding and Consumer Behaviors: Scientific Models (pp. 113-132). New York, NY: Springer.

Macdonald, E. K., \& Sharp, B. M. (2000). Brand Awareness Effects on Consumer Decision Making for a Common, Repeat Purchase Product: A Replication. Journal of Business Research, 48, $5-15$. 